\title{
Implementation of School-Based Management in Padang Indonesia
}

\author{
Hadiyanto \\ Department of Education Administration, Faculty of \\ Education, \\ Universitas Negeri Padang \\ Padang, West Sumatera, Indonesia \\ hadiyanto@fip.unp.ac.id
}

\author{
Yulianto Santoso \\ Department of Education Administration, Faculty of \\ Education, \\ Universitas Negeri Padang \\ Padang, West Sumatera, Indonesia \\ Yuliantosantoso2015@gmail.com
}

\begin{abstract}
This study aims to explore the implementation of school-based management in the Junior Secondary schools in the city of Padang. More specifically, this study aims to compare: 1) autonomy, 2) collaboration, 3) stakeholder participation, 4) transparency, and 5) accountability of SBM in the Junior Secondary schools in Padang. The population is all Junior Secondary schools in the city of Padang totaling 99 schools, while the sample is taken respectively 32 schools. The instrument used in this study is a multiple-choice questionnaire that had been tested for validity and reliability. Data were analyzed using SPSS Program for Windows. The results indicate surprisingly that in general the implementation of the principles of school-based management in Public Junior Secondary Schools is higher (2.95) than Private Junior Secondary Schools (2.75). The difference on the principle of accountability is the only one that is statistically significant. The results of the study suggest that the government has to strengthen the implementation of better school-based management in private schools.
\end{abstract}

Keywords - school-based management; autonomy; partnership; cooperation; community participation; transparency; accountability;

\section{INTRODUCTION}

Improving the quality of human resources through education in Indonesia to date is still reaping criticism and challenges and even assessing the failure. According to the Human Development Index [1], HDI Indonesia is 0.617 , ranked 124 of 187 countries. Wheras according to UNDP (2015), in 2014, Indonesia's HDI is better than in previous years, that is 0.684 , or it is in the order of 110 of 188 countries. HDI Indonesia from 1980 continued to rise above Vietnam, but still below Thailand. This means that Indonesia is still experiencing problems of human resource development in the field of education.

Among the problems and challenges facing the Indonesian nation in the implementation of education, among others: 1) The low quality and accountability of government, especially those responsible for education issues, 2) Education management has not run effectively and efficiently, and 3) education development budgets are not yet adequately available [2]. The quality of education is strongly influenced by the cost of education provided by the state [3]

Several efforts in the field of education have been undertaken by the Government of Indonesia, such as improving the legislation, updating the curriculum, increasing the budget, improving and completing the facilities and infrastructure to improve the quality of educators and education personnel, and improving the quality of education management. Especially in improving education management, according to Nandika can be implemented by improving the autonomy and decentralization of education management in educational units effectively and efficiently, transparently, responsibly, accountably, and participatively [4].

In that context, the government has established a policy by implementing a school-based management model (SBM). This school management model has actually been implemented in countries such as Canada and Australia in the 1970s [5] and in the United States, New Zealand from the 1980s [6], Hong Kong, Chile, China, Germany, Poland, Russia, Uganda, and Zimbabwe [7]. In Indonesia this model was introduced starting in 1999 under the name of School Based Quality Management (MPMBS) by using APBN subsidy of Quality Management Operational Assistance [8]. MPMBS is the pioneer of SBM implementation in Indonesia [9].

Juridically, implementation of School-Based Management in Indonesia was only implemented in 2003 based on Article 51 of The Government Regulation Number 20 the Year of 2003 and Article 49 of The Government Regulation Number 19 the Year of 2005. That policy gives more optimal authority to the school so it is expected to spur schools to improve academic and nonacademic achievement of learners by utilizing all the potential of its stakeholders. Indriyanto states that the approach used in the implementation of this SBM is through the school (school approach), community (community approach) and through the District approach[10].

This SBM implementation has actually shown a positive indication because SBM can spur the potential of the school to become a better performing school[11]. Most (56.28\%) of schools that are piloting SBM implementation are known to be implemented with good management despite poor economic conditions and $30.34 \%$ implemented with good management 
under favorable economic conditions [12]. In the international context, that SBM can: 1) improve the quality of graduates, 2) increase opportunities for district to make decision[13], 3) increasing the effectiveness and efficiency of financing[14] so that according to Rodriguez[15], Ogundele and Adelabu[16] it could improve the quality of the teachers and in turn will improve the quality of the students.

The implementation level of school-based management in some countries is described by Gertler, et al [17], and Osorio et al[18] that the autonomy and community participation in the implementation of education in Indonesia is still not optimal compared to Guatemala, New Zeland, Qatar and the United States.

In addition to sources that positively support the implementation of SBM, such as the ERIC Development Team[19], and Caldwell [20] still show findings that have not fully supported SBM. Some cases indicate that the implementation of SBM in Indonesia is actually bringing in inefficiencies in education management networks in districts and schools and even in the community. For example, some mass media contain articles such as "Implementing SchoolBased Management prone of Corruption"[21], "ICW Findings, MBS Creating New Corruption Model"[22]. "School Based Management Open Opportunities for Illegal Charges'[23], MBS Experiencing Fund Leakage'[24]. Tempo Interaktif[25] writes corruption in schools increasingly. Indonesian Corruption Watch (ICW) smell out the implementation of SBM into a corruption field in school's environtment, organizers and education managers[26]. Bandur also pointed out that the implementation of school-based management In Indonesia still creates problems that cannot be avoided[27].

Some of the problems that arise above if not prevented from the beginning, will be a new virus that thrives in the environment of district/city governments, schools and even people who are collaborating diligently want to improve the quality of implementation education. Indonesia since 2003 has been introducing and fostering school-based management through International Standard School (RSBI) program, National Standard School (SSN), and School Based Quality Improvement Program[28]. However, in subsequent developments RSBI and SSN sparked a polemic up to trial in the Constitutional Court and finally the Indonesia Government stops the program. Furthermore, Directorate of Junior Secondary School since 2005 has implemented School Based Quality Improvement Program (PPMBS). This program Starting from the Regional Education Development and Improvement Program (REDIP) initiated by Japan International Cooperation Agency (JICA), on pilot projects in Central Java and North Sulawesi. The program was later adopted by the Directorate of Junior Secondary School, Ministry of Education and Culture, with APBN funds being implemented in Bogor and Bekasi districts of West Java and Tangerang District of Banten Province. Since 2007 the program has been developed with greater emphasis on the growth of community participation. In 2015 PPMBS involving public and private Junior Secondary Schools in Bekasi City, South Tangerang City, Tangerang City, and Bandung City.
The implementation of the above piloting program is expected to improve the principles of SBM as mandated by legislation. However, what is the condition of regions that do not receive the piloting, is the school has been able to implement the principles of SBM. With the basic descriptions and problems that have been stated above, it is necessary to study or assess the implementation of school-based management in schools that are not the government piloting. The results of this study are expected to be a benchmark in school-based management implementation decisions, both in pilot schools and in larger area.

\section{RESEARCH METHODS}

This study was conducted with a comparative quantitative approach comparing the implementation of SBM in and Private Junior Secondary School in Padang City. Data were collected by using questionnaires that have been tested for their validity and reliability. The study population was 99 Public Junior Secondary Schools and Private Junior Secondary School in Padang City, the research samples taken with the number of 34 schools, consisting of 24 Public Junior Secondary Schools and 8 Private Junior Secondary Schools. Data analysis is done by using T-test application.

\section{RESULTS AND DISCUSSION}

\section{A. Implementation of SBM Principles}

Implementation of principles of school-based management (autonomy, cooperation, participation, transparency and accountability) at Public Junior Secondary School And Private Junior Secondary School in the city of Padang illustrated on the findings contained in the following figure.

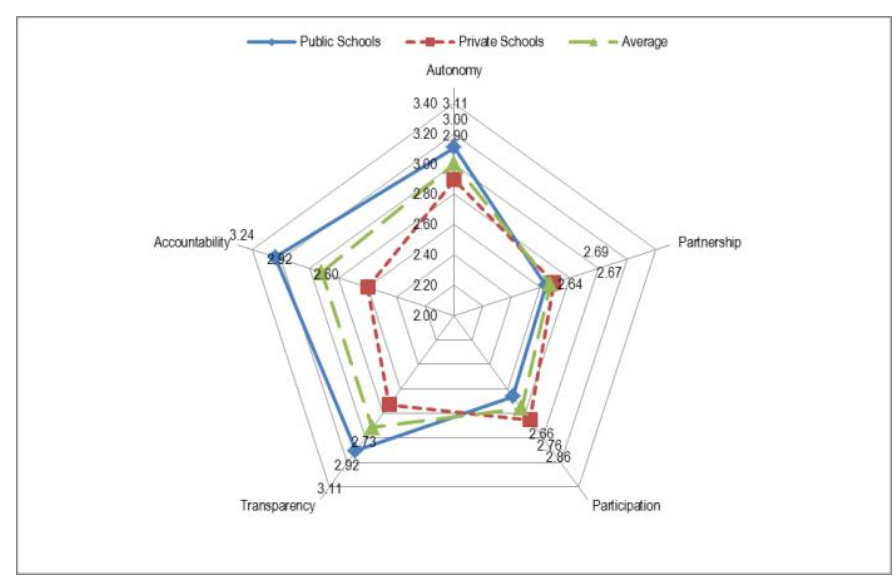

Figure 1 Comparison of Implementation of Principles of School Based Management at Public and Private Junior Secondary Schools in Padang City

From the graph can be seen that first, the autonomy of SBM in Public Junior Secondary Schools (3.11) is slightly higher than that in Private Junior Secondary Schools (2.90) in Padang City. The difference is not statistically significant. Second, the partnership conducted by Public Junior Secondary Schools (2.64) is slightly lower than that in Private Junior Secondary Schools (2.69) in Padang City. The difference is not statistically significant. Third, stakeholder participation received by Public Junior Secondary Schools (2.66) is slightly lower than Private Junior Secondary Schools (2.69) in Padang City. The difference is not statistically significant. Fourth, the transparency of SBM in Public Junior Secondary Schools 
(3.11) is higher than in Private Junior Secondary Schools (2.73) in Padang city. The difference is not statistically significant. Fifth, accountability of SBM in Public Junior Secondary Schools (3.24) is much higher than in Private Junior Secondary Schools (2.60) in Padang City. The difference is statistically significant.

Finally, the overall implementation of SBM principles in Public Junior Secondary Schools $(2,954)$ is higher than in Private Junior Secondary Schools (2.75) in Padang City. The difference is not statistically significant, as ilustrated in the following figure.

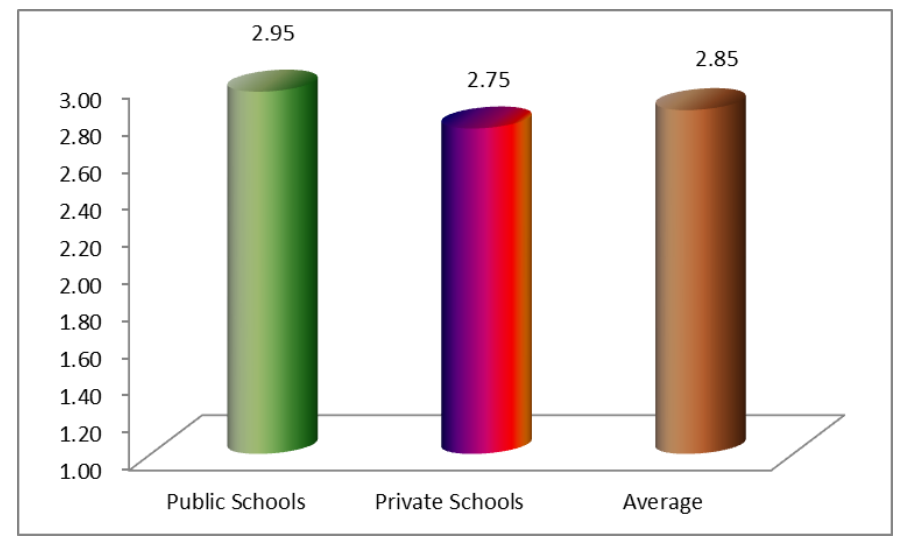

Figure 2 Comparison of the Overall Implementation of School-Based Management at Public and Private Junior Secondary Schools in Padang City

The findings above show that in general the implementation of SBM principles in public schools are higher than that in private schools. This is a new phenomenon because private schools actually have more freedom in policy making on all principles of SBM. This finding is strongly associated with School Operational Assistance (Bantuan Operasional Sekolah/ BOS) fund provided by the government to all schools, both public and private ones. Thus, all of the above SBM principles become more closely related and are bound by rules of use of funds that are fully regulated by the government. In addition, the private schools which originally regulate school finance based on the regulation of foundation, now are moving to regulate the school finance based only on the government regulation about School Operational Assistance (BOS). Consequently, there is no difference in management in public schools with private schools. In addition, since public schools are more accustomed to school financial management under government regulations, the accountability is significantly higher than private schools.

\section{CONCLUSSION AND RECOMMENDATIONS}

With the basis of data analysis and discussion that has been done in the previous section, the conclusions of the study are: 1) There is no significant difference between the implementation of the principle of autonomy, partnership, participation and transparency in public and private Junior Secondary Schools in Padang; 2) The implementation of accountability principles in Public Junior Secondary School is higher than Private Junior Secondary School in Padang City.
The difference in the implementation of accountability principles is statistically significant.

Among the factors contributing the implementation of SBM principles in Public Junior Secondary School do not differ significantly with in Private Junior Secondary Schools is the dominance of government regulations in the distribution and the use of educational funds, especially School Operational Assistance (BOS). The dominance of this regulation makes the principle of autonomy and the participation of the community are not implemented optimally. Therefore campaigns on the financing of education from the government, both by the central government and the government should motivate more opportunities for community participation. In addition, the government should provide training to private school principals in financial management so that they can manage their school finances more transparently and accountably.

\section{REFERENCES}

[1] Human Development Index.2013http://datakesra.menkokesra.go.id/sites/default/files/pen didikan_file/human_developement_index_2011.pdf.

[2] D. Nandika, Pendidikan di Tengah Gelombang Perubahan. Jakarta, LP3ES, p. 6. 2007.

[3] Supriyoko, Pendidikan Manusia Indonesia. Jakarta, Kompas. p. 420 2004.

[4] D. Nandika, Pendidikan di Tengah Gelombang Perubahan. Jakarta, LP3ES, p. 7. 2007.

[5] I. Abu-Duhou, School Based Management. Paris, International Institute for Educational Planning, United Nations Educational, Scientific and Cultural Organization. p. 36. 1999.

[6] L. Brady, Curriculum Development. New York, Prentice Hall, p. 4. 1992.

[7] Cheng, Y. Cheong. 1996. School Effectiveness \& School-based Management, a Mechanisme for Development. London, Falmer Press, p. 44.

[8] Umaedi, Manajemen Mutu Berbasis Sekolah/Madrasah (MMBS/M), Mengelola Pendidikan dalam Era Masyarakat Berubah. Jakarta, Center for Education Quality Management. p. 240, 2004.

[9] Kementerian Pendidikan Nasional Republik Indonesia. Pembangunan Pendidikan Dasar di Indonesia: Menuju Pendidikan untuk Semua. Jakarta, Kementerian Pendidikan Nasional. p. 225. 2011.

[10] B. Indriyanto, 'School-Based Management: Issues and Hopes toward Decentralisation in Education in Indonesia', paper presented at the Third International Forum on Education Reform: Education Decentralization Revised: School Based Management, September 8-11, 2003, Bangkok, Thailand. p.8. 2003.

[11] I. Arifin, Strategi dan Implementasi Desentralisasi Pendidikan di Sekolah Dasar.Studi Kasus MI Jenderal Sudirman Malang. Malang, Dinas Pendidikan Kota Malang. p. 78, 2002.

[12] Umaedi, 2004. Manajemen Mutu Berbasis Sekolah/Madrasah (MMBS/M), Mengelola Pendidikan dalam Era Masyarakat Berubah. Jakarta, Center for Education Quality Management. p. 245.

[13] H. Watson, Report on Evaluation of School Based Management. ACT Department of Education and Training. p. 6. 2004.

[14] P. Coleman, Improving Schools by School-based Management. McGill Journal of Education, Vol.19 No.1 (Winter), 1984.

[15] T. A. Rodriguez, and J. R. Slate, Site-Based Management: A Review of the Literature. Kansas City: University of Missouri.

[16] J. A. Ogundele and Adelabu, M. A.Improving Pupils Quality through Community Advocacy: The Role of School-Based 
Management Committee.The Journal of International Social Research. Volume 2 / 8 Summer 2009.

[17] P. Gertler, A. Patrinos, M. R. Codina, Methodological Issues in the Evaluation of School-Based Management Reforms. gertler@haas.berkeley.edu. Accessed 12th February 2016.

[18] F.B. Osorio, T. Fasih, H.A. Patrinos, L. Santibanez, Decentralized Decision-Making in Schools, The Theory and Evidence on SchoolBased Management. Washington DC, The World Bank. p. 25. 2009.

[19] ERIC Development Team. School-Based Management and Student Performance. ERIC Digest, Number 62. Hh. 1-7. www.eric.ed.gov. Accessed 16th April 2015.

[20] B. J. Caldwell, School-based Management. Paris, The International Institute for Educational Planning (IIEP), 2005.

[21] Suara Pembaruan, 'Pelaksanaan Manajemen Berbasis Sekolah Rawan Korupsi', 1st December 2003.

[22] Media Indonesia, 'MBS Ciptakan Model Korupsi Baru' 11th November 2003.

[23] Sinar Harapan, 'Kebocoran dana Pendidikan' 21st October 2003.

[24] Pikiran Rakyat, 'MBS Mengalami Kebocoran Dana', 28th October 2003.

[25] Tempo Interaktif, 'Korupsi di Sekolah Makin Merebak', 24th October 2003.

[26] Sinar Harapan, 'Manajemen Berbasis Sekolah Buka Peluang Pungutan Liar'. 3rd November 2003,

[27] A. Bandur, The Implementation of School-Based Management in Indonesia: Creating conflicts in regional levels. Journal of NTT Studies 1 (1) 2009, p. 29.

[28] Kementerian Pendidikan Nasional Republik Indonesia. Pembangunan Pendidikan Dasar di Indonesia: Menuju Pendidikan untuk Semua. Jakarta, Kementerian Pendidikan Nasional. p. 10. 2011. 